\title{
Genealogy and Objectives of Economic Science
}

\begin{abstract}
Zahid Siddique
Abstract

This paper is an attempt to explain the relationship between subjective elements of social sciences and the framework in which they have evolved and found their research program. We have been encouraged to undertake this exercise by the call for Islamization of social sciences, especially economics, among Muslim scholars. Most of these efforts have begun within the framework of maximization hypothesis. Islamic Economics within neoclassical framework is justified only if neoclassical economics provides some value neutral framework for analyzing economic behavior of an individual which is not the case. Attempts towards Islamization of social sciences fail to understand that social sciences especially economics, offer justification for the capitalistic order overlooking its sociopolitical agenda. This paper explains that all social sciences relate the liberal philosophy to society through symbolic abstract models.
\end{abstract}

\section{INTRODUCTION}

The last few decades have seen an increasing trend of Islamization of social sciences among Muslim scholars (Rehman, 1988 and (Ma'ruf, 1986). The extent to which modern social sciences reflect a set of subjective values of enlightenment thinkers, instead of objective facts, and the context in which they operate are usually neglected by the Muslim scholars. Social sciences relate liberal philosophy to society through the symbolic creation of abstract models. This paper attempts to explain the links among the subjective traits of social sciences, especially of economics, and the framework in which they have evolved and conducted their research. We are of the view that a two-fold agenda have been the research program of modern economic science: (1) to provide technology in order to legitimize the capitalist social order according to the liberal values and thereby, (2) justify the liberal ideals of political philosophy. Thus, we strictly reject the claims of value-neutrality regarding economic science. Economics represents the liberal society by a model in which each individual exists in an isolated cell of self-interest maximization connected to the rest of society only through the voluntary relationships based on exchange of goods and services. Self-interested individuation and social harmony are seen as mutually reinforcing and, hence, harmonious. The body is seen as the primary instrument dedicated to the only legitimate objective of accumulation for its own sake. On the basis of such a model, 
perfect competition finds justification as a system that most nearly meets the desire for accumulation. The formation of government to organize society is undertaken by the infallible general-will of the citizens of a society. Government is supposed to provide a neutral framework within which people can pursue their own preferences based on their own conceptions of good. The questions of 'right preferences' and 'origin of production technology' are deliberately kept aside. Policies are advocated to move the actual world towards the ideal world of perfect competition where everybody is involved in the quest for accumulating more and more.

The objective of this paper is to highlight the link between this ideal of social organization and its broader framework, called liberalism. It is argued that this theoretical link is not accidental, but relates closely to an individualistic ideology which systematically eschews questions of moral values regarding right and wrong ends of life. Furthermore, results presented in social sciences have moral implications and are not purely abstract information. Social sciences, if, studied in complete abstraction from all human values would be insubstantial disciplines. For example, it is not possible for an economist to maintain that he is merely studying the techniques of adapting limited means to multiple ends without taking account of the source and justification of these ends at the first place. Therefore, a paradigmatic restatement of modern social sciences, especially of economics, is necessary for their proper understanding. Section 2 briefly explains the general framework applicable to all social sciences while Section 3 spells out the special role of Economics in providing a justification for liberal social order. Given the fact that there are a number of distinctive economic schools of thoughts, the reference point of our inquiry of economics will be neoclassical economics.

\section{Defining PARAdigms}

The Enlightenment is a fallout of modernity ${ }^{80}$ emerging in Europe and North America during the $17^{\text {th }}$ and $18^{\text {th }}$ centuries. Philosophers were convinced that religion offers a secondary type of reasoning presuming something as dogmatic, such as its belief system. Science, to them, on the other hand, was a methodology through which we can discover some absolute universal truths without any arbitrary presumption. ${ }^{81}$ The Enlightenment is defined as a condition of the 'maturity of human intellect' from external reliance for its guidance ${ }^{82}$ just like when a child grows mature, he needs no external reliance for himself. Similarly, to these philosophers, man had now grown

\footnotetext{
${ }^{80}$ Modernity may be defined as a historical era (roughly beginning in the third quarter of the sixteenth century in some parts of Western Europe) when human self-determination is socially accepted as a self-evident end in itself and reason is dedicated to the pursuit of human self-determination. 'Humanity' is the central theoretical construct of Enlightenment (Modernist) epistemology as well as ontology (see Habarmas 1989, introduction p. x-xiv)

${ }^{81}$ Immanuel Kant, Critique of Pure Reasoning, (trans.) J. M. D. Meiklejohn, (Columbia University, 1787)

${ }^{82}$ Immanuel Kant, "What is Enlightenment?", in Kant on History (USA: MacMillan Library of Liberal Arts, USA, 1989)
} 
enough mentally to feel himself free to use his intellect for his guidance without any external control. However, it was until the 1960's when Kuhn (1970) explicitly explained the role of the belief system, what he calls Paradigm, in any scientific research program with these words: "A scientific community cannot practice its trade without some set of received beliefs" $"$. These beliefs form the foundation of the "educational initiation that prepares and licenses student for professional practice" ${ }^{84}$. Research, to him, is "a strenuous and devoted attempt to force nature into the conceptual boxes supplied by professional education" $"$. A shift in professional commitments to shared assumptions takes place when an anomaly " ${ }^{86}$ "subverts existing tradition of scientific practice., 87

These shifts are what Kuhn describes as scientific revolutions-"the traditionshattering complements to the tradition-bound activity of normal science" ${ }^{\text {"88 }}$. A new paradigm requires reconstruction of prior paradigms leading to reevaluation of prior facts, reframing of old problems and finding new pathway for evolutionary change. ${ }^{89}$ This is difficult and time consuming. It is also strongly resisted by the established community. When a shift takes place, "a scientist's world is qualitatively transformed [and] quantitatively enriched by fundamental novelties of either fact or theory" ${ }^{\prime 90}$. Paradigms gain their status because they are more successful than their competitors in solving problems. Thus, Kuhn correctly recognizes the revolutionary role of a paradigm in the direction of development and scope of any scientific research. Key reason for this fact is that no observation can be independent of the conceptual framework, language and theoretical system of the observer. 'Neutral' and 'objective' empirical work, where facts speak for themselves is an impossible dream. ${ }^{91}$ Popper recognized the importance of theorybound interpretation of observations as, "they are interpretations in the light of theory". ${ }^{92}$ We find that social sciences are also paradigm-bound as they have flourished within a certain type of mind-set about the world and have worked for the promotion of their particular world-view.

\section{Elements of Social Science Paradigm}

${ }^{83}$ Thomas Kuhn, The Structure of Scientific Revolutions (Chicago: Chicago University Press, 1970), 4.

${ }^{84}$ Ibid., 5.

${ }^{85}$ Ibid.

${ }^{86} \mathrm{An}$ empirical result is called anomaly if it is difficult or if implausible assumptions are necessary to "rationalize" it within the existing paradigm.

${ }^{87}$ Thomas Kuhn, 6 .

${ }^{88}$ Ibid., 7.

${ }^{89}$ Hazel Henderson, Paradigms in Progress (USA: Knowledge System Inc., 1991)

${ }^{90}$ Ibid.

${ }^{91}$ Geoffrey Hodgson, Economics and Institutions (Oxford: Polity Press, 1988), 35-36.

${ }^{92}$ Karl Popper, The Logic of Scientific Discovery (London \& New York: Routledge, 1959), 107. 
A social science paradigm can be built upon the presupposed answers to two questions. There have been two prominent paradigms in the history of mankind that claim to answer these questions. Table 1 lists the questions along with the answers given by these two major paradigms. It is important to note that the Western paradigm is only a representative of the Humanistic paradigm dating from the antiquity. The Islamic paradigm is taken to be a representative of religious worldview.

It is apparent that the direction of any social science crucially depends on answers of these two questions. These questions form a constellation of concepts, values and practices which are shared by a community that forms a particular view of reality according to which the community organizes it. In fact, the first question is related to the conception of human self while the second is concerned with the epistemological foundations of the conception of good. Differences in the sources of discovering the truth has resulted in the differences of scope and progress of knowledge within the two paradigms; that is one seeks to explain the universe in the light of revelation while the other tries to work it out through reason and observation. We will briefly discuss the origins of social sciences within the Enlightenment before taking on the special role of economics within social sciences.

Table 1: Structure of a Social Science Paradigm

\begin{tabular}{|c|c|c|}
\hline Questions & Western Paradigm & Islamic Paradigm \\
\hline 1. The Concept of & & \\
\hline $\begin{array}{l}\text { Human Being } \\
\text { a. His status in } \\
\text { the universe }\end{array}$ & $\begin{array}{l}\text { Sovereign/Indepen- } \\
\text { dent/autonomous }\end{array}$ & Subservient to God \\
\hline $\begin{array}{l}\text { b. Concept of } \\
\text { his life }\end{array}$ & $\begin{array}{l}\text { Related to this world } \\
\text { only }\end{array}$ & $\begin{array}{l}\text { Created by God for a specific time } \\
\text { in the world, along with life after } \\
\text { death (akhirah) }\end{array}$ \\
\hline c. Telos & $\begin{array}{l}\text { Seeking pleasure/self- } \\
\text { fulfillment }\end{array}$ & $\begin{array}{l}\text { Seeking the approval of God } \\
\text { through His obedience. }\end{array}$ \\
\hline $\begin{array}{l}\text { 2. Source of } \\
\text { Knowledge }\end{array}$ & Reason and experience & $\begin{array}{l}\text { Revelation [specifically in the } \\
\text { form of Holy Quran and Sunnah } \\
\text { of the Holy Prophet (SAAW) }{ }^{93} \text { ] }\end{array}$ \\
\hline
\end{tabular}

Enlightenment and Social Sciences

To understand the objectives of social sciences, one must remind oneself of the cultural changes that took place under the name of Enlightenment at the times of Kant and Hegel. This intellectual movement, that also went under the name of liberalism,

${ }^{93}$ SAAW stands for Sallalla ho A'laihi Wa Alehi Wa Sallam, meaning 'Peace Be Upon Him and His followers'. 
emphasized 'freedom' as the ultimate goal and the individual as the 'ultimate entity' in the society. ${ }^{94}$ The nature of this transformation is summarized by Tawny as:

"Dr Figgis has described the secularization of political theory as the most momentous of the intellectual changes which ushered in the modern world....The political aspects of the transformation are familiar. The theological mould which shaped political theory from middle ages to the seventeenth century is broken; politics becomes a science, ultimately a group of sciences, and theology at best one science among others. Reason takes the place of revelation, and the criterion of political theory is expediency, not religious authority. Religion, ceasing to be the master interest of mankind, dwindles into a department of life with boundaries which it is extravagance to overstep." ${ }^{95}$

Thus, after rejecting God in practice, the new deity was defined in terms of freedom, the core concept of Enlightenment. Freedom is the rejection of the religious ideals of the ultimate authority, and this is exactly how Kant defined Enlightenment:

"Enlightenment is man's exodus from his self incurred immaturity. Immaturity is the inability to use one's understanding without the guidance of another person. This immaturity is self incurred if its cause lies not in the weakness of the understanding, but in (the) indecision and lack of courage to use mind without guidance of another. Dare to know! Have the courage to use your own understanding; this is the motto of Enlightenment. ${ }^{.96}$

Thus, with an emphasis on reason, "the Enlightenment philosophers were inclined to reject beliefs in traditional (religious) authority. ... The mission of the practical and change-oriented philosophers of the Enlightenment was to overcome these irrational systems. ${ }^{, 97}$ Having rejected the authority of religious (Christian) epistemology (Bible), these philosophers were faced by the challenge to answer the question 'how society should be regulated by public (government) policy'.

The answer that social scientists developed in response to this question can be traced back to two major presumptions. First, their minds were struck by the belief that the physical world was governed by natural laws, so there might also be natural laws governing human beings. A large number of European scholars including Jeremy Bentham (1748-1832), August Comte (1798-1857), Karl Marx (1818-1883), Herbert Spencer (1820-1903) and Sigmund Freud (1856-1939) were indeed convinced that such laws existed and they tried to seek the secret of human motivation (Baradat, 2000). The greatest inspiration regarding scientific determinism was brought about by Isaac Newton (1642-1727); with his theories of

\footnotetext{
${ }^{94}$ G. Hodgson, Economics and Institutions (Oxford: Polity Press, 1988)

${ }^{95}$ Richard Tawney, Religion and the Rise of Capitalism (Harmondsworth Penguin, 1959), 23.

${ }^{96}$ Immanuel Kant, "What is Enlightenment", 1.(emphasis added)

${ }^{97}$ George Ritzer, Sociological Theory (McGraw Hill, 2000), 11. (emphasis added)
} 
universal gravitation, mass and movement; and Charles Darwin (1809-1882), with his biological theory of natural selection. The effect of this scientific determinism went so deep in the minds of scholars that Comte, one of the pioneering sociologists, developed social physics, which he later termed sociology, following the hard sciences ${ }^{98}$. Therefore, the enlightened philosophers set themselves the task to discover those natural laws and tendencies using reason and research that govern society, as stated by Walras (1874), a pioneer of neoclassical economics:

"In fact, the whole world may be looked upon as a vast general market made up of diverse special markets where social wealth is bought and sold. Our task then is to discover the laws to which these purchases and sales tend to conform automatically. To this end, we shall suppose that the market is perfectly competitive, just as in pure mechanics we suppose to start with, that machines are perfectly frictionless." 99

Walras clearly understood the task before the social scientists; i.e. to give a conceptual framework that governs the society. Such conceptual framework is necessary because the question of appropriate public policy for regulating society could not be addressed without having a model of the formation of society on the basis of freedom, the ultimate value. It is only after having this conceptualization of social formation that these philosophers could address the question of the wise and legitimate government of the state for the common good of the whole society. The major objective of social sciences was to provide this conceptualization of society, (that is, what society is and how it works).

The second factor that played crucial role in the development of social sciences was social evolution which came from the Darwinian view of the process of 'natural selection' in the physical world. An important influence in this regard on sociology was the work of Comte who developed his evolutionary theory with the law of three stages. According to this theory, the world has undergone three intellectual stages throughout human history. The first one he calls Theological stage (prior to 1300 $\mathrm{AD}$ ), which emphasizes that the belief in supernatural powers and religious figures modeled for human kind (prophets) is the root cause of everything. The second stage is metaphysical stage (1300-1800) characterized by the belief that abstract force like nature, instead of personalized gods, explain everything. Finally, the world entered the positivistic stage defined by belief in science when people left the quest for absolute good, and concentrated on observation of physical and social world in the search for laws governing them. Spencer (1820-1903) went a step ahead of Comte and applied the idea of the 'survival of the fittest', which he extracted from Charles Darwin's theory of natural selection, to society, called Social Darwinism ${ }^{100}$. It proposes that if unhampered by external intervention (like government), people who

\footnotetext{
${ }^{98}$ Ibid.

99 Leon Walras, Elements of Pure Economics, 84.

100 G. Jones, Social Darwanianism and English Thoughts: The interaction between Biological and Social Theory ( N.J: Atlantic Highlands, Humanities Press, 1989)
} 
were 'fit' would survive and prosper whereas the 'unfit' would eventually die out. ${ }^{101}$ Spencer suggested that the wealthy were so favored because they were biologically superior to the poor; therefore, the possession of great wealth set the owner apart as a particularly worthy individual. With this, he endorsed Adam Smith's idea of laissezfaire, i.e. government must not intervene in the individuals' sphere of actions, which is controlled by the independent reality of the market, except for their protection. The idea of social evolution was so deeply rooted in Karl Marx's thoughts that Engels made a comparison between Darwin and Marx as: 'As Darwin discovered the law of development of organic nature, so Marx discovered the developmental law of human history'. ${ }^{102}$ Thus, the belief in the presumption of scientific determinism and social evolution was the deriving force behind the intellectual quest of social scientists in their search for the conceptualization of society.

\section{Broader Framework of Social Sciences Research Program}

The above commentary shows that the justification of social conceptualization depends upon the presumption about the conception of human being (his status and objective in this world) and belief in the behavior of society in the course of history. The formal relationship between individual, society and state is depicted by the diagram on the next page. This also shows how practical world policies interact with theoretical models of society. To begin with, the theoretical world starts with the presumed value-laden conception of human being that allows social scientists to work out the theoretical models of society. Those models justify both, particular form of government and public policy recommendations. However, the practical world moves the other way round (look at the outer-dotted arrows emanating from government policies). Here, the social institutions are used to implement the modelderived public policies which raise and sustain the presumed individuality so that the society can be directed towards the theoretical model. The more society works in accordance with the model, the more the policies are legitimized. Nevertheless, we can see that the presumed individuality, that allowed policies in the theoretical world, is not justified on rational grounds, rather accepted as belief system. It is in the acceptance of this particular individuality where the values of the society are grounded. Any change in the conception of individuality leads to changes in social values as well as forms of government and recommended public policies.

This clearly shows that a conceptualization of society cannot be value-neutral because it has to presume the nature of human being for its ultimate foundation. And if the conceptualization cannot be neutral at the first place, the claims of the neutrality of public policies are dismissed thereby. Thus, we find the claim of valueneutrality regarding modern social sciences as unrealistic. It will be explained in the next part that the primary concern of the Enlightenment social scientists was to

101 Ibid.

${ }^{102}$ Leon Baradat, Political Ideologies $7^{\text {th }}$ ed., (New Jersey: Prentice Hall, 2000), 163. 
think what we should do on the earth right now, rather than what we might do to reach the heaven in the future, that 'the essential purpose of the invention of (neoclassical) economics and sociology is to realize the Enlightenment objectives of self fulfillment and material progress' where ' $m a n$ is seen not a part of creation and servant of God, but a potential creator and a master of nature' who is free to make the world as he wishes to. ${ }^{103}$ The only relevant authority was the self's desire as put by Bentham ${ }^{104}$ (1789): 'Nature has placed mankind under the governance of two sovereign masters, pain and pleasure. It is for them alone to point out what we ought to do as well as to determine what we shall do", (emphasis added) or by Mill as: 'Over himself, over his own body and mind, the individual is sovereign., 105

Figure 1: The General Framework of Social Sciences Research Program to Interlink the Theoretical and Practical Worlds

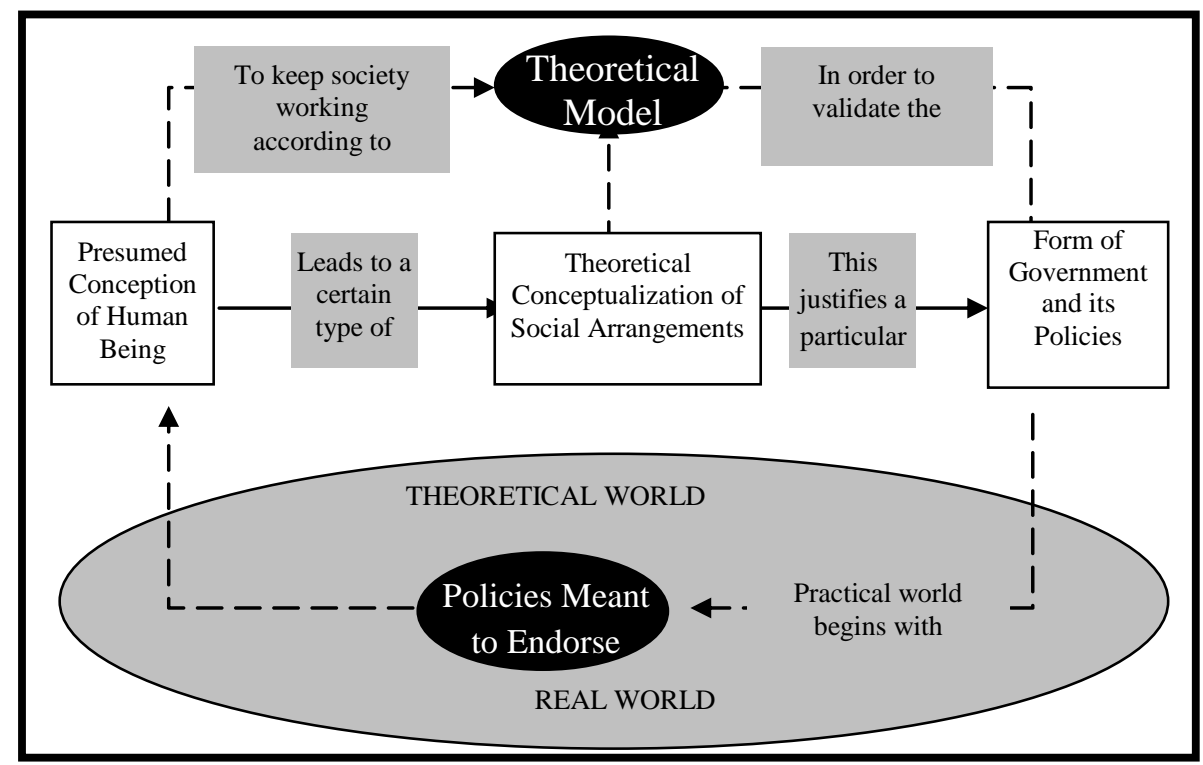

103 Javed Akbar Ansari, "Rejecting Freedom and Progress: The Islamic case against Capitalism", Jareedah 29 (2004): 62. University of Karachi Press

104 Geremy Bentham, An Introduction to the Principle of Morals and Legislation; reprinted (Oxford, UK: Blackwell, 1948).

${ }^{105}$ J. S. Mill, On Liberty (London: Longmans Green and Co., 1865), 6. 


\section{Conceptualization of Society in Economics}

We would now explain the appropriate role of neoclassical economics, as the reference point for social sciences, in providing the technology to legitimize a particular type of social order, called Capitalism (which is based on laissez-faire doctrine), that emerged after the decline of feudalism and patronage in England which generated new divisions in society and economic relationships; that of wageearner to employer. The means of production were owned by a new class of capitalists, who employed labor, and not by the craftsmen themselves. The economic surplus was appropriated by the capitalists through contract in the form of profit and used to put more laborers at work enhancing output largely which necessitated the active search for markets. The demand of this rising capitalist class was that of free trade. The political motivation of such a movement came from the emergence of a distinctive class of manufacturers, whereas its theoretical rationale came from Adam Smith (1723-1790), the unanimously accepted Father of Economics.

\section{Smith's Vision and Modern Economics}

In order to understand the appropriate role of economics within capitalism, we need to look into Smith's vision of an ideal society.

\section{Five-aspects of Smithian Discourse}

'Vision' is the ideology which presents a picture of things as 'we want to see them' ${ }^{106}$ Smith's vision of things as they ought to be in the socioeconomic order originated from the ideology of the Enlightenment. In the Wealth of Nations, Smith was fundamentally concerned with the question, 'what is a just economy?' $\mathrm{He}$ characterized the just society by these features: (1) a well governed state (to be explained below) in a country that has reached a high level of affluence, (2) a community committed to social justice (explained below), (3) perfect liberty for individuals to make their own decisions, (4) a world order in which all nations are parts of a liberal system of free trade. ${ }^{107}$

In the Wealth of Nations, Smith argues that the poor society existing in eighteenth century Britain could be transformed into his ideal state through appropriate policies. Smith identified physical productivity, the ability of labor to produce surplus product, as the main instrument for achieving the ultimate goal of the 'affluent society'. If we presume the five books of Wealth as five aspects of Smith's thesis, we will see that all of these lead to a single underlying idea; that is productivity. In Book I, Smith talks about the determinants and impact of the division of labor on the wealth of nations; the central idea of Book II is justification of the 'virtue' of savings, investment and capital formation; Book III argues that the natural order of productivity growth runs from agriculture to manufacturing to foreign commerce. In Book $I V$, Smith lists the forces that motivate individuals to

106 J. A. Schumpeter, A History of Economic Analysis", (ed.) E. B. Schumpeter (London: George Allen and Unwin, 1954), 41-42.

107 Adam Smith, The Theory of Moral Sentiments (New York, 1971), 350, 354. \& Adam Smith, An Inquiry into the Nature and Causes of the Wealth of Nations (New York : 1973), 56, 78-79, 462, 464, 506, 509. 
undertake productive activities; and Book $V$ explains the role of the state in enhancing productivity growth through the provision of defense, 'justice' and public goods. The whole Smithian discourse focuses on the idea that physical productivity is the foundation on which the wealth of nations can be built.

\section{Central Argument of Economics for Capitalist Order}

Neoclassical economics sees social order as founded on economic, not on political or religious, foundations that define their own moral order subordinate to the economic rationality of accumulation. The formal economic justification of such a social order begins with the assumption of scarcity, that is, we don't have all of the resources we think we want. Scarcity arises due to a mismatch between our desires and talents to satisfy those desires. The economic notion of scarcity is not that something is 'rare', but rather that it is perceived as rare by consumers. Since any single resource can be put to alternative uses, the allocation problem requires it to be used where it produces maximum utility. In fact, subjective scarcity is the crux of the Neo-classical theory of value. Given the set objective of utility maximization, economics starts its analysis with the assumption of a rational utility maximizing individual as the basic element of society, called methodological individualism, the view that the basic element of analysis in social sciences should focus on the individual decision makers and that all economic phenomena can be ultimately explained by aggregating over the behavior of individuals. ${ }^{108}$ Someone must be making decisions, and for Neo-classical economics, it is the individual. ${ }^{109}$ The individual is assumed to have taste and talent and he/she computes benefits and costs at the margin to maximize his/her personal gains or satisfaction, called utility. The taste of the individual, as summarized by utility, indicates his preferences between alternative consumption patterns including leisure. His talent determines his ability to satisfy these preferences using his productive abilities. Given a constraint on his available resources, the individual is left free to choose any combination of the goods that satisfy this constraint and provides him the maximum level of individual satisfaction according to his own preferences. The presence of general scarcity and competitive society will put pressure on each individual to choose a point where his personal valuation of a good is in line with the objectively determined valuation of that good by the market.

The important question for a theoretical foundation of society on the basis of individual as the basic entity is this: since each individual is in pursuit of his own freedom (wants), it is possible that the freedom (wants) of one may erode the freedom (wants) of another. This is put by Friedman (1982) as: "The basic problem of social organization is how to co-ordinate the economic activities of large numbers of people... The challenge to the believer in liberty is to reconcile this widespread interdependence with individual liberty." 110 Why reconciliation of

${ }^{108}$ Lawrence A. Boland, The Foundations of Economic Methodology (London: George Allen and Unwin, 1982) \& G. Hodgson, Economics and Institutions (Oxford: Polity Press, 1988)

${ }^{109}$ Kant (1787) terms this ability of a person to make free, rational choices a person's autonomy.

${ }^{110}$ Milton Friedman, Capitalism and Freedom (Chicago: University of Chicago Press,1982), 11-12. (emphasis added) 
individuals' activities be addressed at all? It is important because, given equal freedom to each individual to pursue his objectives/preferences in his own way, the society as a whole can reconcile individual interests only when there is no conflict of interests among individuals within society. To Smith, the answer to this question was the division of labor. Smith argues that wealth is determined by the physical productivity of laborers, which in turn depends upon the division of labor. But the problem is that as individuals get more and more specialized in their talents, their mutual dependence on each other also increases for satisfying their particular taste. The extension of division of labor is possible when individuals enter into exchange to obtain goods they want for their use. And the expansion of these exchange relationships allows more people to specialize and, therefore, have more goods for consumption in total. ${ }^{111}$ The division of labor is determined by the size of the market and the size of the market is dependent upon the amount of goods and number of people willing to engage in exchange. Will people feel it in their interest to come together to exchange? Yes: since each individual has different taste for different units of consumption, including the opportunity cost of supplying inputs, and he has different talents, any single individual, most likely, will not be able to satisfy his own taste using his specific talents alone. It is for this reason that individuals will gain advantage by specializing in the field of production. As a result, in order to maximize utility, individuals are willing to supply particular inputs for the production of a variety of goods for the satisfaction of the taste of other people expecting the exchange of goods he desires. Hence, social relations are the relations of exchange based on voluntary contracts between individuals where everybody feels that there is a personal benefit from their particular role in exchange. Smith (1776) speaking on how the cooperation between humans is motivated says:

“.....man has almost constant occasion for the help of his brethren, and it is in vain for him to expect it from their benevolence only. He will be more likely to prevail if he can interest their self-love in his favor, and show them that it is for their own advantage to do for him what he required of them.....We address ourselves not to their humanity but to their self-love..."112

Thus, the readymade answer to the problem of harmonizing the individual's activities is free exchange, also called voluntary exchange, because each individual is entirely selfish and is the best judge of his own welfare. It follows that all interactions among individuals must be based on free choice ${ }^{113}$ and, thus, voluntary contract provides sufficient conditions for the attainment of an economic based social system where no individual enters into a contract to buy or sell unless it is in his/her own interest and where complex interrelationships among individuals can exist. Given the independence of individuals to make decisions in their own

${ }^{111}$ It is in this sense that individual gains cannot be taken apart from social prosperity for Smith.

${ }^{112}$ Adam Smith, An Inquiry into the Nature and Causes of the Wealth of Nations, 14.

${ }^{113}$ Yair Aharoni, The No Risk Society (New Jersey: Chatham House Publishers, 1981) 
interests, the society is seen as the sum total of the individuals who compose it. The beauty of this whole process is, as defined by Cole, Cameron and Edward (1983):

"no conscious agent is needed to choose a price for a good, and that sum total of individual tastes and talents is sufficient to determine a price, and that such a price will guide resource allocation towards efficiency, equity and stability"114

Thus, we find that after accepting the underlying assumptions about the nature of human existence (utility maximization), we reach the unavoidable conclusion that a society always has a possible situation in which a set of prices exist that link all members of the society through voluntary contracts or exchange. No violation of freedom is necessary to produce cooperation among individuals all of whom can benefit. ${ }^{115}$ Such a working model of society organized through voluntary exchange among free individuals acting in response to an acquisitive self-interest, unhampered by governmental regulation and restrained by the forces of an effectively-functioning competitive market is a 'free private enterprise exchange economy', called capitalism.

Starting with a pre-social and individual economic rationality (utility maximization) and the dissolution of authority on a hierarchical structure (equal freedom to all to pursue their preferences), the question of the formation of society is addressed through free operation of market whereby people with different, but morally equal, preferences come across each other in the market under mutually beneficial social contracts so as to obtain means or resources to satisfy their own preferences (or wants or objectives) respecting those of others. The underlying basis for making these social contracts, as demonstrated above, is their capacity to facilitate individuals to accumulate as much resources as possible in order to realize their sovereignty; that is their ability to exercise their own conception of the good. Indeed, this sovereignty could only be exercised with the help of resource accumulation; the more means you have, the more freedom you enjoy to pursue your preferences or wants. Thus, it is the market that becomes the corner stone of a society, or society becomes a market under such a social organization. A market society, also called a civil society, is one where self-interest seeking individuals get involved in the social contract in order to accumulate maximum resources to realize their freedom. The mutually beneficial and binding social contracts in the market establish the necessary conditions that lead to the attainment of maximum individual freedom, and this freedom, in turn, can be materialized only through the accumulation of maximum resources. Self-interestedness and social harmony are seen as mutually harmonizing and 'social harmony requires that the individual be oriented to the pursuit of his self-interest.' This 'self-interest commits the individual to accumulation' of resources, i.e. 'to a continuous never ending amassment of means for realizing one's ends. Accumulation is therefore the only' rational 'end in itself in capitalist order and necessarily becomes the basis for ascribing value to all practices. ${ }^{116}$ In Smithian commercial society, the only moral

\footnotetext{
${ }^{114}$ Ken Cole, John Cameron, and Chris Edwards, Why Economists Disagree, The Political Economy of Economics ( London: Longman group limited, 1983), 70.

115 Ibid.

${ }^{116}$ Ansari.
} 
commitment is the 'growth of capital' which is seen as an end in itself. The economic value is determined by the relative assessment of each individual's act in the contribution of capital accumulation. Values, such as a definitive conception of good, are no longer given meaning with adherence to some transcendental religious moral conception because capitalism defines all such norms with reference to accumulation, the sole merit of capitalism. Thus, capitalist society is justified on the bases of material progress and acceleration in the rate of accumulation is the necessary requirement of social justice.

Therefore, '(neoclassical) economics is not a positive science in any sense. It is not a technology applicable to any end. It presumes equal triviality of all ends and preference orderings. Without accepting this presupposition, the claim that economic rationality enables the optimization of preference fulfillment is meaningless. This is so because economic rationality structures transactions to prioritize accumulation and such a society necessarily articulates preference for preference.'117 Schumpeter's (1954) description of political economy as 'an exposition of a comprehensive set of economic policies that its author advocates on the strength of certain unifying (normative) principles such as the principle of economic liberalism, of socialism and so on ${ }^{, 118}$ confirms the normative nature of modern economics. All institutions of markets and state are theorized as technical instruments that enable free utility and profit maximizing individuals to practice their rationality.

\section{Role of Government}

Government, says Friedman (1982), is a form of voluntary cooperation, a way in which people choose to achieve some of their objectives through governmental entities because they believe that is the most effective means of achieving them. With this interpretation, the best government is the representative form of government as stated by Jefferson, "The will of the people... is the only legitimate foundation of any government, and to protect its free expression should be our first object." ${ }^{119} \&^{120}$ Through such a government institution, each individual votes in favor of his or her preferred option that best suits his/her own objectives.

The existence of free markets working efficiently does not rule out the need for government. However, the role of market is to minimize greatly the range of issues to be decided through political means and thereby reduces the need for direct government intervention in the society. The advantage of the market is that it permits wide diversity whereas the major feature of political channel is that it enforces substantial uniformity. Actions through the government channel require substantial conformity, that is most of the issues at hand have to be decided in 'yes' or 'no' form. The number of separate groups that can be represented and the provision that can be made become fairly limited with governmental course of action. Most importantly, the final outcome reached takes the form of a 'law' that is

${ }^{117}$ Ansari, 77.(emphasis added)

118 J. A. Schumpeter, A History of Economic Analysis", (ed.) E. B. Schumpeter, (London: George Allen and Unwin, 1954), 38.

${ }^{119}$ Thomas Jefferson, "Declaration of Independence", The Writings of Thomas Jefferson Memorial Edition (ME) (Lipscomb and Bergh, ed. (Washington, D.C., 1903-04) 10: 236

${ }^{120}$ Also see Locke (1956) for the similar analysis. 
mandatory to all groups instead of separate legislative enacted for each party, which could destroy any possibility of consensus on which unanimity without conformity can be based. Political version of proportional representation, in this sense of neglecting unanimity without conformity, bends towards ineffectiveness and disintegration. Therefore, the use of political channels put strain on social cohesion that is essential for a stable society. If the number of issues that require joint agreement for an action on which people have common views is limited, the strain on the delicate threads that hold society together will be least. The widespread use of market reduces the pressure on this social fabric by letting conformity unnecessary with respect to all activities that are rendered by the market. "The wider the range of activities covered by the market, the fewer are the issues on which explicit political decisions are required and hence on which it is necessary to achieve agreement. In turn, the fewer the issues on which agreement is necessary, the greater is the likelihood of getting agreement while maintaining a free society." 121

Market in this sense is viewed as a system of proportional representation where each man can vote for the goods he wants and get it without worrying what the majority wants. It is this feature of the market that is held responsible for providing 'economic freedom' to the individuals. Thus the goal of individual freedom held by the liberals as the ultimate criterion for judging the social arrangements, according to Friedman (1980), is realized by free private enterprise society. Such a social system is also compatible with the political thoughts of liberals that require minimum government intervention in the freedom of individuals. ${ }^{122}$ It is this framework that outlines the role of a government in a society whose participants desire to achieve the greatest possible freedom to choose their own interests as they see them as individuals, as families, as members of voluntary groups and as citizens of an organized government. The market must, therefore, be allowed to operate unfettered by state intervention except when intervention is necessary to prevent the exercise of monopoly power, to mediate market failures or to preserve an orderly monetary framework. The state is supposed to be an instrument for the protection and promotion of the moral sentiments and property forms that are appropriate to the capitalist form of social order characterized by: (1) Capitalist individuality dominated by accumulation and competition, and (2) Capitalist Property that organizes production and exchange with the objective of continuous expansion of capital and the subjugation of all valuation to the logic of capital accumulation. ${ }^{123}$ Since self-interestedness is assumed to be self-enforcing and harmonious, and each individual is assumed to be the best judge of his own welfare, the government has little role to help individuals achieve their own

\footnotetext{
${ }^{121}$ Rose Friedman \& Milton Friedman, Free to Choose (New York \& London: Harcourt Brace Jovanovich, 1980), 24.

The objective of preserving human liberty to make choices can be traced back to the second formulation of Kant's categorical imperative according to which the essence of immorality is to subvert the ability of a person to make free, rational choices, named autonomy. Thus, the fundamental duty of a government must be to respect individual's autonomy if it is to be a moral government.

122 Stephen Mulhall \& Adam Swift, Liberals and Communitarians (Oxford: Blackwell publishers, 1992)

${ }^{123}$ Ansari, 71.
} 
objectives. The government is supposed to remain neutral. Since the power of the state derives from the amount of freedom each individual is willing to sacrifice, democratic governments are justified so long as they correctly interpret the general will and design policies consistent with the universal objective of accumulation of capital. The only legitimate interpretation of the public freedom by the political intelligentsia takes the form of public economic policy, and nothing more. The problem of economic policy is to ensure that the tastes of individuals can be expressed freely and that each individual can exercise his talent independently. This whole theoretical agenda of economics, from utility maximization to the role of government, is shown in figure 2 which is directly comparable to our general framework in figure 1 .

Figure 2: The Theoretical Agenda of Economics in the General Framework

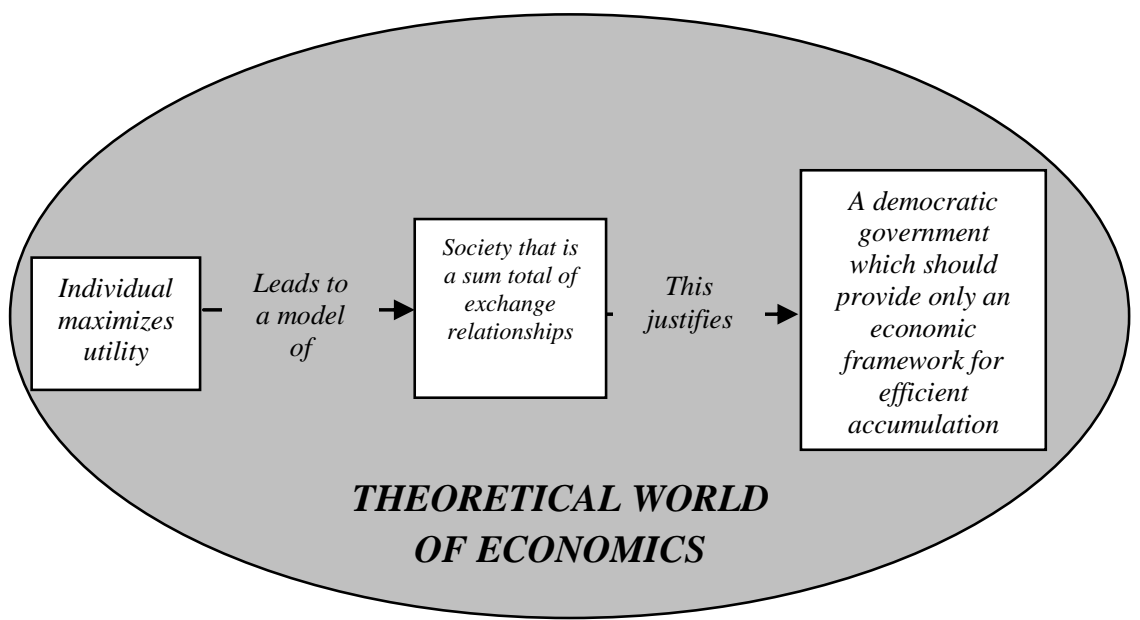




\section{Conclusion}

The social sciences, especially economics, are not positive sciences in any sense, rather built upon the premises, assumptions and postulates that are diametrically opposed to those of Islamic thoughts. For social sciences, e.g. in anthropology, even religion along with everything else concerned with human beings, like culture, values, beliefs, even the concept of God, is a product of some natural and social evolutionary process. The evolutionary paradigm, after Darwin, has become a universally accepted paradigm for all behavioral sciences in the Western world. This paradigm sees no weight in Prophethood and revelation as determining factors of civilizations over the history of mankind. Social sciences offer an epistemological justification of society and state without any reference to God and revelation.

Economics endorses self-interested, greedy and competitive individuation as natural, negates love-based social organizations in favor of social-contract, legitimizes market-oriented liberal state policies and articulates society based on material grounds - not religious. Justifying economic science means legitimizing liberal capitalist values and transaction forms on Islamic grounds. Therefore, we believe that no formula can serve as a magic stick whose swing can turn an atheistic system into a theistic one, much less than an Islamic one. Attempts towards the Islamization of social sciences fail to see the underlying conceptualization of society that social sciences offer for the justification of capitalist order; that is they overlook the socio-political position of social sciences. This negligence of researchers, regarding the departure of Western paradigm of moral and political philosophies from those of Islamic, allows them to portray Islamic social content in an extended form of the social sciences framework and, thus, to provide theoretical justification to treat Islam as a special case of capitalist social order [for detailed discussion of this issue, see (Siddique, 2005)]. It is the fact that such attempts incorporate social sciences framework that naturally restricts their scope to create any revolutionary impact through their policy implications on the justification of capitalist society based on methodological individualism. 